\title{
Cumulative Contents
}

Editorial

The way ahead

$P$ Harris

management of paraplegia

$R$ Carter

International Medical Society of Paraplegia-11 years on

$H$ L Frankel

Fifty years on fundamentals in spinal cord injury care are still important

$G$ Bedbrook

Paraplegia: views from the Chief Scientist Office

D Dodwell

The spinal cord injury primary physician. One riot-one ranger

J $S$ Young

A message from Dr David F Apple Jr MD

An appreciation of Paraplegia, the International Journal of The Spinal Cord,

and its role as a coordinator of information

B P Gardner

The scientific committee of the International Medical Society of Paraplegia

P Dollfus

Neural transplants in spinal cord injury

J C Horvat

The evolution of the spinal cord unit: East and West

W H Donovan

Spinal cord injuries in the 21st century

$P$ Harris

Spinal injury in Scotland

$P$ Edmond

Spinal injury associations: a British perspective

J Hart

The evolution of neuroimaging of spinal cord injury patients over the last

decade

$M$ Perovitch, $H$ Wang and $S$ Perl

Spinal injuries: early surgical treatment

$R$ A Dickson

Conservative versus surgical treatment of the cervical and thoracolumbar

spine in spinal trauma

$M$ E Brooks

Neurourology in spinal cord injured patients

$J J$ Wyndaele

Sexual dysfunctions in the spinal cord injured

$R$ Stien

Psychosocial research in spinal cord injury: the state of the art

$R B$ Trieschemann

Bioengineering developments for paraplegic patients

$J$ C Barbenel and J P Paul

The current state of the management of the upper limb in tetraplegia

$D W L a m b$

Progress of comprehensive rehabilitation of patients with spinal cord lesions in 
FW Meinecke

Rehabilitation: some thoughts on progress

I Bromley

Clinical rehabilitation research advances in spinal cord injury

$J$ A DeLisa

Meetings and Notices

Spinal cord injuries: the last decade and the next

D J Brown

Spinal cord repair: future directions

$J W$ Fawcett

Indian spinal injuries centre

A S Chahal

New spinal cord injury standards, 1992

Ditunno Jr

Development of neurophysiological aspects of the spinal cord during the past

ten years

$M R$ Dimitrijevic

Neural prostheses: clinical applications of functional electrical stimulation in spinal cord injury

P H Peckham and G H Creasey

Pharmacological treatment of acute spinal cord injury: current status and

future prospects

$M$ B Bracken

Community reintegration and quality of life following spinal cord injury

$M J$ De Vivo and J S Richards

Postural thixotrophy: a significant factor in the stiffness of paralysed limbs?

E G Walsh

Pressure sores: a personal comment

J C McGregor

The role of intracavernous injection of vasoactive medications for the

restoration of erection in spinal cord injured males: a three year followup

$D R$ Bodner, B Leffler and F Frost

The effect of intermittent positive pressure breathing on lung volumes in acute

quadriparesis

$K$ Stiller, $R$ Simionato, K Rice and B Hall

The effect of intravesical Marcain instillation on hyperreflexic detrusor

contractions

P D McInerney, A Grant, J Chawla and T P Stephenson

Long term follow up of spinal cord injury caused by penetrating missiles

$M E$ Brooks, $R$ Brouner and A Ohry

The management of spinal cord injury patients in Greece

$C$ B Petropoulou, Ch-A G Rapidi, M Beltsios, $G$ Karantonis and

$\operatorname{Pr}$ E Lampiris

Spinal cord injury due to suicide attempts

F Biering-Sørensen, $W$ Pedersen and P Giфrtz Müller

Obituary

E R Griffiths

GM Pool

Meetings and Notices

Bladder pressure and kidney function in children with myelomeningocoele:

review article

$R L$ Vereecken 
Hangman's fracture in Singapore (1975-1988)

ES Tan and $N$ Balachandran

Human osteoblast stimulation by sera from paraplegic patients with

heterotopic ossification

$M H J$ Kurer, $M$ A Khoker and P Dandona

Prophylactic low dose heparin anticoagulant therapy in patients with spinal

169

cord injuries: a retrospective study

$J R$ Kulkarni, A A Burt, A T Tromans and P D L Constable

Suicide following acute traumatic spinal cord injury

$F K$ Judd and D J Brown

Modified Brown-Séquard syndrome following coronary artery bypass graft:

case report

M H Gottesman, I Saraya and F Tenti

Brown-Séquard syndrome due to Semple antirabies vaccine: case report

HS Swamy, A Vasanth and Sasikumar

evaluation of the effect of dextropropoxyphene hydrochloride in therapy

$L S$ Andersen, $F$ Biering-Sørensen, $P G$ Müller, I L Jensen and

$B$ Aggerbeck

Sexual issues of women with spinal cord injuries

$S W$ Charlifue, $K A$ Gerhart, $R R$ Menter, $G G$ Whiteneck and

MS Manley

Septic ischial bursitis in patients with spinal cord injury

$S$ Rubayi and J Z Montgomerie

Increased serum osteocalcin levels in patients with paraplegia

P Pietschmann, P Pils, W Woloszczuk, $R$ Maerk, D Lessan and J Stipicic

Anourethral reflex. Description of a reflex and its clinical significance:

preliminary study

A Shafik

The social and vocational outcome of spinal cord injury patients

$M$ Taricco, C Columbo, $R$ Adone, $G$ Chiesa, S Di Carlo, M Borsani,

$E$ Castelnuovo, $G$ Ghirardi, $R$ Lascioli and A Liberati

The management of an old fused hip after the occurrence of paraplegia

$M D$ Ryan and J J Henderson

patient: case report

$S G$ Carroll, $S F$ Bird and D J Brown

Meetings and Notices

227

Laufband locomotion with body weight support improved walking in persons

with severe spinal cord injuries

$A$ Wernig and $S$ Müller

Ambulation using the reciprocating gait orthosis and functional electrical

stimulation

E Isakov, $R$ Douglas and $P$ Berns

Physiological cost index of paraplegic locomotion using the ORLAU

ParaWalker

$A V$ Nene and $S J$ Jennings

Voiding by increased abdominal pressure in male spinal cord injury patients -

long term follow up

A Greenstein, $K S$ Rucker and $P$ G Katz

Bladder outlet resistance decreasing operations in spinal cord damaged 
Exertional hypertension in thoracic spinal cord injury: case report

$M L$ King, D M Freeman, J T Pellicone, ER Wanstall and L D Bhansali

The effectiveness of a pressure clinic in preventing pressure sores

$H$ Dover, W Pickard, I Swain and D Grundy

The role of intracavernosal vasoactive agents to overcome impotence due to

spinal cord injury

C M Earle, EJ Keogh, J K Ker, D J Cherry, A G S Tulloch and D J Lord

Ossification of the posterior longitudinal ligament in the thoracic spine causing

intermittent paraplegia in an Englishman: case report

$H$ Nakamura, $H V$ Crock, B P Galbally and J Dawson

Health and psychosocial issues of individuals with incomplete and resolving

spinal cord injuries

$K A$ Gerhart, $R$ L Johnson and $G G$ Whiteneck

A second traumatic spinal cord injury: associated risk factors. Case report and

review

$J$ A Sliwa, A C Lim and E J Roth

Preoperative embolisation, transpedicular decompression and posterior

stabilisation for metastatic disease of the thoracic spine causing paraplegia

$S Y$ Bhojraj, A V Dandawate and R Ramakantan

The role of motor evoked potentials in the management of hysterical

paraplegia: case report

$D$ A Jellinek, $R$ Bradford, I Bailey and L Symon

Meetings and Notices

303

Current advances in magnetic resonance imaging (MRI) in spinal cord

trauma: review article

$M$ Perovitch, $S$ Perl and $H$ Wang

Psychological and sociological theories concerning adjustment to traumatic

spinal cord injury: the implications for rehabilitation

$K R$ Whalley Hammell

Use of penile prostheses to maintain external condom catheter drainage in

spinal cord injury patients

I Perkash, J N Kabalin, S Lennon and $V$ Wolfe

Studies of bladder sensitivity in patients with myelodysplasia

277

282

288

292

300

$J J$ Wyndaele

Endoscopically guided bladder neck suspension for continence in paraplegic

women with implant driven micturition

$L$ Cardozo and $G S$ Brindley

Hyperpyrexia in spinal injury patients

$A$ Essiet and $O$ Onuba

Bone mineral and hormone status in paraplegics

$V$ Finsen, $B$ Indredavik and $K J$ Fougner

Cardiovascular and vasoactive hormone responses to bladder distension in

spinal and normal man

H Krum, W J Louis, D J Brown, S J Clarke, J A Fleming and L G Howes

Fatal cerebral hemorrhage due to autonomic dysreflexia in a tetraplegic

patient: case report and review

I Eltorai, $R$ Kim, M Vulpe, H Kasravi and W Ho

Is the appearance of periarticular new bone formation related to local

336

neurological disability?

A Catz, D Snir, Z Groswasser, L Mendelson and P Solzi

Long term follow up of patients with cauda equina syndrome due to intraspinal lipoma

A Ohry, M Azaria and G Zeilig 
Surgical considerations in patients with lumbar spinal root anomalies

$M N$ Pamir, M M Özek, A F Özer, G E Keleş and C Erzen

Thigh compartment syndrome secondary to intertrochanteric hip fracture in a quadriplegic patient: case report

$R$ L Rimoldi and D A Capen

Meetings and Notices

Risk factors for cardiovascular disease in chronic spinal cord injury patients

H Krum, L G Howes, D J Brown, G Ungar, P Moore, J J McNeil, W J Louis

The role of the diaphragm in trunk extension in tetraplegia

C Sinderby, P Ingvarsson, L Sullivan, I Wickström, L Lindström

The neurosensory musculocutaneous tensor fasciae latae flap: long term results

W Kuhn, NJ Luscher, $R$ de Roche, S Krupp, G A Zäch

Changes in thyroid hormones, thyroid stimulating hormone and cortisol in acute spinal cord injury

J M Bugaresti, C H Tator, J D Silverberg, J P Szalai, D G Malkin, A Malkin, $S$ K Tay

The effects of sauna on tetraplegic and paraplegic subjects

H J Gerner, P Engel, G C Gass, E M Gass, T Hannich, G Feldmann

Vocational decision making by sixty spinal cord injury patients

R Crisp

Psychological approach to the rehabilitation of the spinal cord injured: the contribution of relaxation techniques

$J$ L Curcoll

Aerobic power of competitive paraplegic road racers

$S$ P Hooker, C L Wells

The value of urodynamics and bladder management in predicting upper

urinary tract complications in male spinal cord injury patients

W Killorin, M Gray, J K Bennett, B G Green

Spinal cord lesion after penicillin gluteal injection

L Tesio, L Bassi, L Strada

Acute paraplegia resulting from haemorrhage into a spinal neurofibroma $S-T$ Lee, $T$-N Lui

Esophageal perforation: a delayed complication following traumatic spinal cord injury. Case report

$S$ Colachis III, K D Murray

Meetings and Notices

The hyperflexed seemingly useless tetraplegic hand: a method of surgical

WJ Treanor, E Moberg and H J Buncke

Effects of functional electrical stimulation (FES) on evoked muscular output in paraplegic quadriceps muscle

E Rabischong and F Ohanna

Reduction of seating pressure using FES in patients with spinal cord injury. A preliminary report.

$A C B$ Ferguson, J F Keating, $M A$ Delargy and $B J$ Andrews

Breathing pattern adjustments during the first year following cervical spinal cord injury

$B$ Loveridge, $R$ Sanii and $H I$ Dubo

An investigation of the relationship between environmental factors and job

satisfaction in intensive nursing, with particular reference to spinal trauma

$O$ Nugent, $C A$ Glass, KR Krishnan and J D Bingley

The algesic syndrome in spinal cord trauma 
A V Livshits

Short-latency somatosensory evoked potentials (SSEPs) of the tibial nerves in spinal cord injuries

A Kovindha and R Mahachai

The measurement of muscle tone

E G Walsh

A comparative study of the muscle strength and mass of the arm flexors and

extensors in paraplegic and in non paraplegic basketball players

P Calmels, S Berthouze, F G Barra, M Domenach and P Minaire

Primary multiple spinal extradural hydatid cysts of the literature: case report

and review

$M$ Bavbek, S Inci, K Tahta and V Bertan

The older adult with a spinal cord injury

E J Roth, L Lovell, A W Heinemann, M Y Lee and G M Yarkony

Pregnancy in a quadriplegic patient treated with continuous intrathecal

baclofen infusion to manage her severe spasticity. Case report.

E M Delhaas and $J$ Verhagen

Book Reviews

Meetings and Notices

Neurological and skeletal outcomes in 113 patients with closed injuries to the

cervical spinal cord

W H Donovan, D X Cifu, D E Schotte

Motor vehicle crashes and spinal injury

E C Wigglesworth

An open trial of vacuum penile tumescence: constriction therapy for

neurological impotence

L Heller, O Keren, $R$ Aloni, $G$ Davidoff

Transcutaneous nitroglycerin in the treatment of erectile dysfunction in spinal cord injured

J Sønksen, F Biering-Sørensen

Mechanical plus pharmacological prophylaxis for deep vein thrombosis in

acute spinal cord injury

G J Merli, S Crabbe, L Doyle, J F Ditunno, G J Herbision

Return to work after spinal cord injury: the potential contribution of physical

\section{$L$ Noreau, $R$ J Shephard}

Maximal exercise response of paraplegic wheelchair road racers

$R$ A Cooper, $S M$ Horvath, $J F$ Bedi, $D$ M Drechsler-Parks, $R E$ Williams

Symptomatic postprandial hypotension in high paraplegia. Case report

A Catz, L Mendelson, P Solzi

Recurrent dislocation of the hip in adult paraplegics

$G$ P Graham, C M Dent, P D Evans, B McKibbin

An outline of the programme of rehabilitation medical services in the People's

Republic of China: 1991-1995

Chen Zhong-Wu

Graves' disease complicating myelopathy

$J$ H Frisbie, $B$ Fisch

The application of a modified neuroprosthetic hand system in a child with a $\mathrm{C7}$

spinal cord injury. Case report

$B T$ Smith, $M J$ Mulcahey, $R J$ Triolo, $R R$ Betz

Meetings and Notices

Recent developments in neurosurgical spinal cord monitoring 
Mortality, morbidity, and psychosocial outcomes of persons spinal cord

injured more than 20 years ago

$G G$ Whiteneck, $S W$ Charlifue, $H$ L Frankel, $M$ H Fraser, B P Gardner,

$K A$ Gerhart, KR Krishnan, $R$ R Menter, I Nuseibeh, D J Short, J R Silver

An audit of five years' experience of pregnancy in spinal cord damaged

women. A regional unit's experience and a review of the literature

$P$ A Feyi-Waboso

Traumatic injury to the spinal cord. Prevalence in Brazilian hospitals

A Campos da Paz, P S S Beraldo, MCR R Almeida, E G C Neves,

$C M F$ Alves, $P$ Khan

Traumatic spinal cord injuries in Turkey

$F$ Dincer, A Oflazer, $M$ Beyazova, $R$ Çeliker, $O$ Basgöze, $K$ Altioklar

A clinical exercise system for paraplegics using functional electrical stimulation

$L A$ Bremner, K E Sloan, $R E$ Day, E R Scull, T Ackland

Tracheostomy in spinal cord injured: frequency and follow up

$M$ Biering-Sørensen, F Biering-Sørensen

Cystic cord lesions and neurological deterioration in spinal cord injury:

661

operative considerations based on magnetic resonance imaging

M Silberstein, O Hennessy

Electromyographic registration of diaphragmatic fatigue during sustained

trunk flexion in cervical cord injured patients

C Sinderby, P Ingvarsson, L Sullivan, I Wickström, L Lindström

Solitary spinal osteochondroma causing neural syndromes

A Prasad, P N Renjen, M L Prasad, G B Bhatty, V S Madan, T B S Buxi,

$S P$ Agarwal

Obituary

Gerald Henry Ungar

Meetings and Notices

Interdisciplinary treatment of spina bifida children

682

$T$ Redaelli, A Cassinis, F Cosignani, B Conti, MP Onofri, A Dall'Acqua

Spinal cord injury: 10 and 15 years after

683

L A Cushman, J Hassett

Depressed serum high density lipoprotein cholesterol levels in veterans with

spinal cord injury

W A Bauman, A M Spungen, You-Gong Zhong, J L Rothstein, C Petry,

$S K$ Gordon

Suggested MRI criteria for surgical decompression in acute spinal cord injury.

Preliminary observations

M Silberstein, D Brown, B M Tress, O Hennessey

Bacterial biofilm formation in the urinary bladder of spinal cord injured

patients

G Reid, R Charbonneau-Smith, D Lam, Yun Suk Kang, M Lacerte,

$K C$ Hayes

Results of the combined treatment of paediatric intraspinal tumours

$F$ Dincer, $C$ Dincer, $M$ K Baskaya

Lumbar spine dimensions in paraparetic patients: a 10 year follow up study

A Catz, I Reider-Grosswasser, I Gutman, R Gepstein, L Mendelson

Postoperative wound infections following myocutaneous flap surgery in spinal

injury patients

M Garg, S Rubayi, J Z Montgomerie

Incidence and risk factors in the appearance of heterotopic ossification in

spinal cord injury

P Bravo-Payno, A Esclarin, T Arzoz, O Arroyo, C Labarta 
Use of the biceps femoris following failed inferior gluteal flap transfer. Case report

W O Thomas, G Bjorn Stark, J O Basadre, SW Parry

Urinary lithiasis induced by sulfamethoxazole in a patient with tetraplegia.

Case report

M Rince, P Dudognon, C Moesch, C Leroux-Robert

Book reviews

Erratum

Meetings and Notices

Assessment of rehabilitation in patients with spinal cord injuries:

\section{$P$ Daverat}

Spinal cord injury: prognosis for ambulation based on quadriceps recovery

$K S$ Crozier, Ling Ling Cheng, V Graziani, G Zorn, G Herbison,

\section{$J$ F Ditunno Jr}

Repeated measurements of pulmonary function following spinal cord injury

$M$ H Bluechardt, $M$ Wiens, $S G$ Thomas, $M J$ Plyley

Lipid profiles in spinal cord injury

D Cardús, F Ribas-Cardús, W G McTaggart

Bladder rehabilitation with dorsal rhizotomy and ventral neuroprosthesis

L S Baskin, $R$ A Schmidt

Vertebral osteomyelitis following manipulation of spondylitic necks - a

possible risk

$M$ Lewis, D Grundy

Physeal injuries in myelomeningocele patients

A Cuxart, J Iborra, M Meléndez, E Pagès

Management of pyogenic vertebral osteomyelitis with spinal cord compression

in the elderly

$R$ Gepstein, Y Folman, C Lidor, $V$ Barchilon, A Catz, T Hallel

A psychological study of spinal cord injured patients involved in the Madras

Paraplegia Project

O Somasundaram, S Balakrishnan, O S Ravindran, $T$ K Shanmugasundaram

Computerized quantitative radionuclide assessment of heterotopic ossification

in spinal cord injury patients

Sun W Kim, Sing Yung Wu, R C Kim

Peripheral nerve block with phenol to treat spasticity in spinal cord injured patients

$S$ Gündüz, T A Kalyon, H Dursun, H Möhür, F Bilgiç

Book Reviews

Meetings and Notices

Editorial

A cross-sectional study of the relationship between age and current health

status for persons with spinal cord injuries

$M J$ DeVivo, $R M$ Shewchuk, $S$ L Stover, $K J$ Black, $B K G o$

Young spinal cord injured patients in nursing homes: rehospitalization issues

and outcomes

$S$ I Weingarden, P Graham

New estimates of the direct costs of traumatic spinal cord injuries: results of a

nationwide survey

$C$ Harvey, $S$ E Wilson, C G Greene, M Berkowitz, $T$ E Stripling

Correlation of bacteriological flora of the urethra, glans and perineum with 
$\mathrm{N}$-nitrosamine generation by urinary tract infections in spine injured patients stimulation in spinal cord injured humans

$M J$ Cohen, $S$ L Schandler, M Vulpe

Enhanced carotid-cardiac baroreflex response and elimination of orthostatic hypotension 24 hours after acute exercise in paraplegics

$K A$ Engelke, $J D$ Shea, $D F$ Doerr, $V A$ Convertino

An examination of dietary intakes and nutritional status of chronic healthy

spinal cord injured individuals

A M Levine, M S Nash, B A Green, J D Shea, M J Aronica

Pregnancy, labor and delivery post spinal cord injury

L L Cross, J M Meythaler, S M Tuel, A L Cross

Oesophageal trauma in patients with spinal cord injury

G M English, Shih-Fong Hsu, R Edgar, M Gibson-Eccles

Meetings and Notices

Indexes

915

Cumulative Contents 